\title{
The Model of Conflict-Handling between Gafatar and the Mempawah Community in the Legal Approach
}

\author{
Sy. Hasyim Azizurrahman ${ }^{1} \&$ Elyta Elyta $^{2}$ \\ ${ }^{1}$ Faculty of Law, Universitas Tanjungpura, Indonesia \\ ${ }^{2}$ Faculty of Social Science and Political Science, Universitas Tanjungpura, Indonesia \\ Correspondence: Elyta Elyta, Faculty of Social Science and Political Science, Universitas Tanjungpura, \\ Indonesia. E-mail: elyta@fisip.untan.ac.id
}

Received: April 20, 2020

doi:10.5539/jpl.v13n2p175
Accepted: May 18, $2020 \quad$ Online Published: May 25, 2020

URL: https://doi.org/10.5539/jpl.v13n2p175

\begin{abstract}
Conflict arises as a result of various forms of difference and importance, but the most common is the difference of opinion. As happened to the community of Mempawah Districts, there was an indication of heresy that runs by the Fajar Nusantara Movement Group (Gafatar). Gafatar had opposite goals with what the local and central government has implemented. This research is to design a model for handling conflicts between Gafatar and the community in the law approach. The research method applied is qualitative. Data collection used interview technique, documentation technique, and narratives. The results of this study have designed models for handling conflicts between Gafatar and the Mempawah community in a legal approach. The research has also emphasized the role of the state and the its military and security apparatus to keep order and solve tribal issues. Resolving the Gafatar group conflict with West Kalimantan MUI is the central case of this study.
\end{abstract}

Keywords: Gafatar, state, police, conflict, law, security

\section{Introduction}

The law approach aims to protect every individual and various actors from various conflicts that occur. The conflict quickly occurs in the world. This perception has made the Mempawah community reject the presence of ex-residents in their villages. The various sides have employed all kinds of arguments and perspectives, and the main ones are religious versus human rights and pluralism (Wiratraman, 2012). One example related to this issue is the Gafatar movement. Gafatar is a group of social movements that carry deviant teachings based on religion and are the result of the teachings of Millah Abraham. Besides that, Gafatar is a form of community upheaval in Indonesia in the current reformation era. The followers of the Gafatar fall into two categories, a group with pure teachings and another group with mixed teachings. Their teaching is due to their lack of understanding of the religion they profess and because of teaching factors without expecting promises.

The existence of such a doctrine is that people voluntarily sell goods and property in their home areas to buy the land where they live based on their agreement. Law is a rule that applies to society, both traditional and modern societies. Naturally, the community will achieve calm and serenity if they provide control, social supervision, both written and unwritten (Arifin, 2020). In this case, Gafatar movements often have caused unrest and disparity in community groups, especially in the West Kalimantan region.

In addition, it also poses a threat to the soul of nationalism because the place where people are powerless to meet their daily needs increases the movement of change to support the welfare of society (Elyta \& Razak, 2019). It cannot be denied that the problem of nationalism is a phenomenon directly related to social society. The area of distribution of the Gafatar group was in the East Mempawah Districts, West Kalimantan Province.

The purpose of Gafatar was as a place to gather the sons and daughters of the archipelago in bringing together an understanding of moral humanity and nationality that is inclusive, solid, intelligent, and united as a means of communication and fostering brotherhood both in Indonesia and in other states in the world. Also, this group tried to maintain and fight for the noble ideals of the nation embodied in the 1945 Constitution's Preamble. The other goals were giving birth to cadres of national leaders who were honest, courageous, assertive, fair, capable, trustworthy, wise, intelligent, and healthy, based on the values and belief in the one and only God. The distribution of the Gafatar group in West Kalimantan in more detail is in Table 1 below. 
Table 1. Distribution of the Gafatar Groups in West Kalimantan

\begin{tabular}{clc}
\hline No & \multicolumn{1}{c}{ Region } & Number of Gafatar Followers \\
\hline 1 & Ketapang Districts & 1.288 people \\
2 & Mempawah Districts & 1.140 people \\
3 & Malawi Districts & 972 people \\
4 & North Kayong Districts & 732 people \\
5 & Kubu Raya Districts & 449 people \\
6 & Singkawang City & 302 people \\
7 & Bengkayang Districts & 267 people \\
8 & Sambas Districts & 131 people \\
9 & Sintang Districts & 131 people \\
10 & Kapuas Hulu Districts & 104 people \\
11 & Landak Districts & 60 people \\
12 & Sanggau Districts & 46 people \\
13 & Pontianak City & 22 people \\
\hline & Total & 5.636 people \\
\hline
\end{tabular}

Source: Suhadi, 2016

Based on Table 1, the total number of Gafatar residents in West Kalimantan is 5,636 people. The spread of the Gafatar group in the three largest regions was Ketapang Districts with 1,288 people, Mempawah Districts with 1,140 people, and Melawi Districts with 972 people. Of the three areas, the one area experiencing conflict was Mempawah Districts.

The Gafatar group conflict began after the circulation of the issue of Doctor Rika, who was reported missing and followed by other news that developed through the media. Media, showing the perpetrator of conflict disproportionally, had caused the material loss for the Gafatar. It is ironic since their life after the conflict has become unstable and without economic prosperity. Indeed, media framing had alienated them from their community (Winarni, Yudiningrum, \& Wijaya, 2017). Besides, public suspicion was increasing when Gafatar residents use the mosque to sing. It seems that the norms of religion were deviating so far that the people declared this to be heretical. These deviant habits resulted in disputes between Mempawah communities and the Gafatar group. The Mempawah community requested that the residents of Gafatar be deemed heretical and deviated from social norms, then immediately evacuated from their territory and returned to their homes.

As an archipelago, Indonesia's population has an uneven distribution. This issue causes population growth that is closely related to and influences various aspects of life, specifically improving the quality of life or human resources (Oktavina, 2020). This issue finally brings multiple forms of deviation and conflicts that ultimately lead to division. The conflict intensified because of the many demands from the people, while the government could not fulfill these demands. They consider the government to take too long to make a decision. The community thought that the government was not responsive to listening to their aspirations, so they were determined to take steps unilaterally. Suspicion of the Mempawah community started when local people may not enter the area inhabited by the Gafatar, and over time, the community became even more suspicious. The conflict arose in the desperate action of the people to expel and burn the Gafatar group's residence to immediately leave the Mempawah area. During the conflict, there was an intervention of many parties, framing them as a victim before the law (Winarni, Yudiningrum, \& Wijaya, 2017). Based on this phenomenon, the researchers are interested in doing further research, namely, to design a model for handling conflicts between Gafatar and the community in the law approach.

\section{Method}

This research used descriptive qualitative method. Data collection applied interview techniques, documentation techniques, and literature studies in the form of newspapers, books, and journals. The researchers interviewed the Commander of Pontianak Districts Military 1207 BS, The Chief of Pontianak Resort Police, Gafatar members, and Mempawah Districts community with the help of interview guidelines prepared following questions related 
to research. The results of interviews and literature studies were continued by analyzing the data to find the results of the investigation.

\section{Results and Discussion}

\subsection{Model of Conflict Handling between Gafatar with the Mempawah's Community}

The result found a model of conflict-handling between Gafatar with the Mempawah's community in the law approach, which consists of two elements. They are (1) the state's role in controlling conflict and law enforcement; and (2) the role of the police in upholding the law, seen in the following chart.

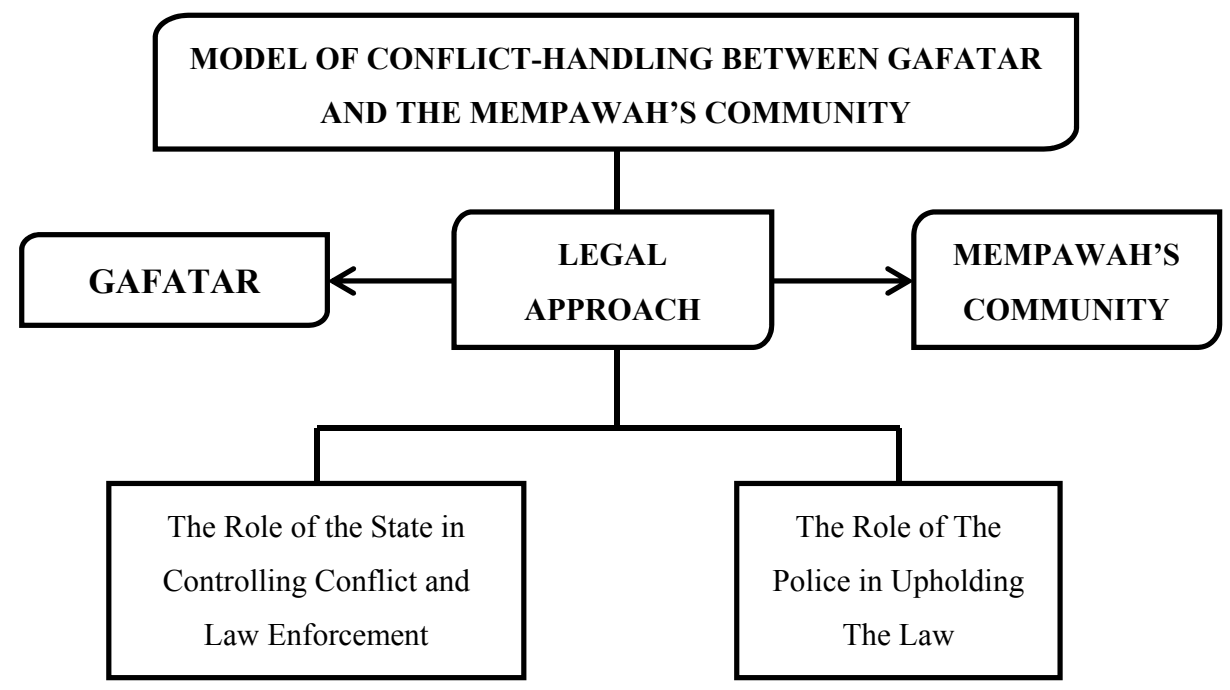

Figure 1. Model of conflict-handling between Gafatar and the Mempawah's community in the law approach Source: Processed by the researchers

\subsection{Role of the State in Controlling Conflict and Enforcing Law}

The development of law in the global sphere has had many influences in many sectors in Indonesia. The dynamics of the legal case and its resolution give out the impression that society is developing quickly and unexpectedly. At the same time, there are laws left behind (Utari \& Arifin, 2019). That certainly requires the role of the state in democratic governance structures.

Changes in a democracy require the role of the community to continue to be publicized and introduced to the community with the aim of keeping the public able to maximize their participation, including in terms of nationalism (Elyta \& Zulkarnaen, 2016). Awareness of the spirit of nationalism of a society is based on the behavior and level of participation in society both social and political participation.

The state is the highest government structure in a region. A good governance system should be a form of government that is responsive and responsible for its people. If there is proper implementation of the system, the chance of conflict will be small. The government only handles the conflict that has occurred, not in eradicating the source of conflict. The Gafatar is an exciting phenomenon in the contemporary era of Indonesia. Based on these results, the research indicated that the government had taken action to repatriate the Gafatar group due to the legal aspect. The legal aspects of the transfer of the Gafatar group are not equipped with transparent population administration, for example, not having Identity Card (IC), not having an IC letter from where they come from to the destination area. In its social aspect, namely rejection, when there is a statement from the West Kalimantan MUI stating that it is a heretical and misleading flow, the reaction arises, the government takes action based on population provisions.

A criminal act using with violence is one of the most common crimes or in Indonesia Community. It happens in every region in Indonesia (Tyas \& Rodiyah, 2020). Besides, a crime without violence also often occurs in Indonesia today. They bring new understandings that are contrary to the ideology of the nation, causing divisions. One of the defactors is the Gafatar movement. Gafatar groups carry out infiltration, which is to enter a region secretly to carry out illegal activities. The Gafatar group came to the West Kalimantan region with no transfer 
letter. They farmed, built barracks without a Building Construction Permit. Gafatar members had a purpose that was not in line with what the local and central government had as rule.

Prolonged conflicts without resolution cause major disputes for a strategy in the form of political agreements is needed to overcome conflicts. Gafatar groups are from Java and Sumatra. They entered the West Kalimantan region clandestinely without going through legal population administration procedures. It underlines the government's reasons for returning them to their original areas. Thus, the inclusion of the Gafatar group into the West Kalimantan region was not prevented from the beginning because it was not through the legal population procedure. After all, it was not in line with the legislation, especially the provisions on population issues. Besides, the government has not been keen enough to see the source of conflict in the social aspects of the refusal of the Gafatar group by Indonesian Religious Leader in West Kalimantan due to the assumption that they are stained with heresy. When the conflict turned into a dispute, the new government seemed too busy to handle it.

The results showed that the people of Mempawah Districts who were unable to stem their anger carried out the burning of a car belonging to a former Gafatar member when holding a meeting with the Regional Leadership Communication Forum chaired by the Mempawah Regent. The Resort Police (Polres) and the Regional Government directly evacuated the incident, leaving the Gafatar group at the Kodim. The evacuation aimed to ensure security and provide facilities for their convenience. For their living costs, such as eating and so forth, the Regional Government paid for them. The Indonesian military officers also conducted training at the Commander of Pontianak Districts Military 1207 BS even though it was slow. The Gafatar group had been brainwashed by misguided ideology which was too complicated to eliminate.

Violence not only arises due to no power but also because of their ability (Tamba \& Masyhar, 2020). This power eventually leads to prolonged conflict. As a result, the conflict eventually became an unfinished state task. The inability of the state to control the conflict appears through, frequent cases of arson and disputes committed by the community still occur here and there. The results showed that the government had paid attention and been responsive to the Gafatar group due to expulsion by the Mempawah community. The government provided facilities and infrastructure in the evacuation process to the process of returning to the area of origin. The government evacuated the Gafatar group at the Kodim as a form of safeguarding them from various threats and the slow formation of the souls of the Gafatar group from deviant understanding.

Recent developments in technology have risen to many new dynamics and relations between the government and other actors, both public and private (Kourula, Moon, Salles-Djelic, \& Wickert, 2019). At present, the role of government in controlling every activity in the country is undoubtedly essential, especially in terms of authority. The government is an authority actor. The aspect of power is one of the critical characteristics of leadership. The position method is a crucial element; each position must have authority because it is always attached to the position. Authority is the authority of the state as a political actor to control problems related to people's lives. Stated that the government controls authority. Authority is an essential part of leadership and in every position, because authority and position are an integral entity.

Thus, the form of authority carried out by the government is by establishing several policies, including the establishment of emergency response status for handling refugees from the Gafatar organization. Determination of these decisions is necessary for the wary of disaster due to refugees' followers of the Gafatar organization to minimize and even eliminate risks in the form of integrated cross-sectoral planning and preparation. This decision resulted in the imposition of the Kubu Raya Districts Regional Income and Expenditure Budget, the West Kalimantan Provincial Revenue and Expenditure Budget, the State Revenue and Expenditure Budget through the National

Disaster Management Agency is a ready-to-use fund and other non-binding funds. Determination of emergency response posts for handling refugees from the Gafatar organization in Kubu Raya Districts. Efforts to guard against the impact of the influx of refugees from the Fajar Nusantara Movement organization in the form of temporary shelter that affects the livelihoods of the refugees. This decision resulted in the imposition of the Kubu Raya Districts Regional Revenue and Expenditure Budget, the West Kalimantan Provincial Revenue and Expenditure Budget, the State Revenue and Expenditure Budget through the National Disaster Management Agency's Ready-to-Use Fund and other non-binding fund.

Determination of the status of emergency is responsive to disaster management of refugees due to followers of the Gafatar organization in Mempawah Districts, West Kalimantan Province. Based on the coercion of the people of Mempawah Districts, they gave orders to the Gafatar group to leave Kubu Raya Districts within three days as of January 14, 2016, at 24.00 WIB. The decision of the meeting between the Muspida and the representatives of the Gafatar group, which had not yet been successful on 24 January 2016 at 24.00 a.m., resulted in the burning of 
one Avansa car in the courtyard of the Mempawah Districts Office. Determination of planned emergency response status was valid for 14 days from January 14, 2016, to January 28, 2016, and stopped if the conditions had not been stable. The Mempawah Districts Regional Budget and Ready-to-Use Budget through the Republic of Indonesia National Disaster Management Agency paid the costs incurred as a result of this decision.

Determination of emergency response status handles disaster for refugees due to followers of the Gafatar organization. Expulsion and burning of residences of followers of the Gafatar organization took place on January 19, 2016. There was an establishment of a policy according to Social Disaster Management Standards and Procedures by creating Emergency Disaster Response Status to deal with the severity of the impact of the disaster. Establishment of refugee disaster response commends due to followers of the Gafatar organization. Expulsion and burning of residences of followers of the Gafatar organization happened on January 19, 2016. Based on the government's decision, they focused attention on the conditions that occurred. The government has always intervened to protect and deal with refugees from the Gafatar group from the evacuation process.

\subsection{The Role of the Police in Upholding the Law}

Crime, murder, theft, robbery, and rape are types of court actions causing the perpetrators languishing and receiving education under the title of Prisoner at the end of their release. Also, they can have a higher degree than a recidivist if they are in and out and become residents of the place (Muslim, 2019). This is all part of the responsibility of the state whose authority is not challenged.

Besides having authority, a country must also have a power monopoly in the government system. The government is an apparatus that has the authority and power to regulate the state. Based on the form of an external power state, power has three parts, namely security, economy, and social power. Indonesian army and police have different tasks and responsibilities. The Indonesian military has to safeguard the integrity of the Republic of Indonesia against various threats, while the National Police are committed to protecting the security of the community. Military and police collaboration is necessary for dealing with state security.

The results of the study showed that the police had three main tasks, keepers of order, protectors of the community, and law enforcers. The first task of the police as maintaining the security of public order means a dynamic condition that must continue when there is anything that affects the condition of stability. The police will take steps. The second task is that the police protect and must determine which party to protect under stressed conditions. The three national task are aspects of law enforcement because the function of legal duties is law enforcement, the law must be enforced, without violating the article and being applied relatively to anyone. The main objective of the Constitution is to place control of foreign relations firmly in the hands of the national government. In this case, conflicts that occur within the country, such as the Gafatar group, need a follow up consistently.

Thus, the three main tasks of the police aim at preventing conflicts that lead to anarchic actions. Police officers are responsible for maintaining the security and welfare of the Gafatar group to avoid anarchist movement. However, many parties, especially the people of Mempawah Districts, think that these residents are followers of heresy. The Indonesian National Army is a state defense institution that is obliged to maintain the unity of the Indonesian state and its people from external threats. However, both the army and the police battalions evacuated Gafatar group back to Bekangdam XII Tanjungpura Headquarters on Adisucipto street.

Furthermore, the results of the study showed that in addition to the police chief, the Indonesian Army also took part in the process of evacuating the former Gafatar members. The Regional Government assigned the Indonesian Army to bring the evacuated Gafatar group to the military dormitory of the Bekangdam XII Tanjungpura Headquarters on Adisucipto street. The refuge was to protect the Gafatar group from mass tantrums and stabilize the situation.

\section{Conclution}

Various forms of differences and interests are vulnerable to conflict, especially in differences of opinion. The Mempawah community considers an indication of heresy, run by residents of Gafatar. This research paper has focused on the model of conflict-handling between Gafatar with the Mempawah's community in the law approach, upholding the law and enforcing the law. The research has also emphasized the role of the state and the its military and security apparatus to keep order and solve tribal issues. Resolving the Gafatar group conflict with West Kalimantan MUI is the central case of this study.

\section{References}

Arifin, R. (2020). Legal Reform Discourse in Indonesia and Global Context: How Does The Law. Journal of Law and Legal Reform, 1(2), 193-196. 
Elyta, E., \& Razak, A. (2019). The Role of Weavers Woman in Strengthening Nationalism (Case Study in Sajingan Besar Frontier, Indonesia). Sosiohumaniora, 40. https://doi.org/10.24198/sosiohumaniora.v21i1.19285

Elyta, \& Zulkarnaen. (2016). Political Participation of Border Communities at Sajingan Besar in Election of Representatives Area. Jurnal Penelitian Dan Pengembangan Pelayanan Publik, 3(2), 39-45. Retrieved from http://jurnal-litbang.kalbarprov.go.id:8088/index.php/litbang/article/view/73/65

Kourula, A., Moon, J., Salles-Djelic, M. L., \& Wickert, C. (2019). New Roles of Government in the Governance of Business Conduct: Implications for Management and Organizational Research. Organization Studies, 40(8), 1101-1123. https://doi.org/10.1177/0170840619852142

Muslim, I. F. (2019). Pre-Release Treatment in Class II A Correctional Institution of Pekalongan. Neurosurgery, 1(1), 93-106. https://doi.org/10.1227/01.NEU.0000192163.55428.62

Oktavina, S. (2020). Population Growth Control Policy and Its Effect to Law Enforcement. Journal of Law and Legal Reform, 1(2), 225-240.

Suhadi. (2016). Kegiatan Gerakan Fajar Nusantara (Gafatar) Serta Indikasi Ajaran Millah Abraham di Wilkum Polda Kalbar. Paper presented by the Director of Binmas of the West Kalimantan Regional Police on April 16, 2016 in the Dialogue of Religious Leaders Organized by the Forum Peduli Ibu Pertiwi, Lembaga Tunas Karya Nyata \&Universitas Tanjungpura.

Tamba, A. R., \& Masyhar, A. (2020). Protection of Victims of Domestic Violence (Study Decision Number: 2660/PID.SUS/2015/PN MDN). Journal of Law and Legal Reform, 1(2), 297-310.

Tyas, D. A. R., \& Rodiyah. (2020). The Handling of Criminal Act of Theft with Violence by Children of the Directorate of Criminal Investigation of the Central Java Regional Police. Journal of Law and Legal Reform, 1(2), 273-278.

Utari, I. S., \& Arifin, R. (2019). Law Envorcement and Legal Reform in Indonesia and Global Context: How the Law Responds to Community Development? Journal of Law and Legal Reform, 1(1), 1-4.

Winarni, L., Yudiningrum, F. R., \& Wijaya, S. H. B. (2017). Social Media and the Issue of "Gafatar" in Indonesia. KnE Social Sciences, 2(4), 115-119. https://doi.org/10.18502/kss.v2i4.876

Wiratraman, R. H. P. (2012). In Search of Constitutionality: Freedom of Expression and Indonesia'S Anti-Pornography Law. Yuridika, 27(2), 111-120. https://doi.org/10.20473/ydk.v27i2.291

\section{Copyrights}

Copyright for this article is retained by the author(s), with first publication rights granted to the journal.

This is an open-access article distributed under the terms and conditions of the Creative Commons Attribution license (http://creativecommons.org/licenses/by/4.0/). 